\title{
GAMBARAN RETIKULOSIT TERHADAP PEMBERIAN OBAT ANTI TUBERKULOSIS (OAT) PADA PASIEN TUBERKULOSIS PARU DI PUSKESMAS PERUMNAS KADIA KOTA KENDARI
}

\author{
Sri Aprilianti Idris ${ }^{1}$ \\ ${ }^{1}$ Prodi Analis Kesehatan, Politeknik Bina Husada Kendari \\ Email: sriaprilianti.aakkdi@gmail.com
}

\begin{abstract}
Background: Tuberculosis is an infection caused by Mycobacterium tuberculosis. Treatment of tuberculosis with anti-tuberculosis (OAT) drugs has toxic effects on hematologic side effects such as anemia, agranulocytosis, eosinophilia and thrombocytopenia. Calculate reticulocytes in patients without anemia between 1-2\%. It is important to be used as an indicator and helps to determine anemia as hyperproliferative, normoproliferative or hypoproliferative.
\end{abstract}

Methode: The method used is supravital (Brilliant Cresyl Blue) with dry preparat.

Result: The result of the research showed that 18 reticulocytes patients who consumed Anti Tuberculosis (OAT) at Perumnas Kadia Kota Kendari Health Center got normal reticulocyte count of 2 people (11\%) and abnormal patients (89\%).

Conclusion: There is an increasing number of reticulocytes in patients taking antituberculosis drugs (OAT)

Keyword: retikulosit, tuberkulosis, anemia

\section{Pendahuluan}

Tuberkulosis adalah penyakit infeksi akibat kuman Mycobacterium tuberculosis yang dapat menginfeksi beberapa organ tubuh, seperti paru-paru, ginjal dan tulang $^{1}$. Laporan WHO tahun 2013 di dunia terdapat 9,0 juta orang terinfeksi tuberkulosis dan 1,5 juta orang meninggal karena penyakit tersebut ${ }^{2}$. Pada tahun 2016 terdapat 10,4 juta kasus tuberkulosis, hal ini sama dengan 140 kasus per 100.000 populasi $^{3}$. Sampai saat ini penyakit tuberkulosis masih menjadi masalah kesehatan yang utama, baik di dunia maupun di Indonesia ${ }^{1}$.

Indonesia merupakan salah satu penderita tuberkulosis paru terbesar kedua setelah India ${ }^{3}$. Penyakit ini juga merupakan penyebab kematian urutan ketiga setelah penyakit jantung dan penyakit saluran pernapasan. Menurut profil kesehatan Indonesia tahun 2015 terjadi peningkatan kasus tuberkulosis paru dari tahun sebelumnya yaitu 324.539 kasus menjadi 330.910 kasus di wilayah Indonesia $^{1}$. Pada tahun 2015 di Sulawesi

Meditory | ISSN Online : 2549-1520, ISSN Cetak : 2338 - 1159, Vol. 6, No. 1, Juni 2018

HIm. 61 - 69, http://ejournal.poltekkes-denpasar.ac.id /index.php/M 
Tenggara ditemukan 3.268 kasus baru tuberkulosis, proporsi kasus tuberkulosis dimasyarakat relatif konstan di semua kabupaten $/$ kota $^{4}$.

Retikulosit adalah sel darah merah (SDM) yang masih muda yang tidak berinti dan berasal dari proses pematangan normoblast di sumsum tulang. Retikulosit biasanya berada di darah selama 24 jam sebelum mengeluarkan sisa RNA dan menjadi sel darah merah ${ }^{5}$. Hitung retikulosit pada pasien tanpa anemia berkisar antara 1-2\%. Jumlah ini penting karena dapat digunakan sebagai indikator produktivitas dan aktivitas eritropoesis di sumsum tulang dan membantu untuk menentukan klasifikasi anemia sebagai hiperproliferatif, normoproliferatif atau hipoproliferatif ${ }^{6}$.

Tingkat maturitas retikulosit dapat menjadi indikator klinis aktivitas eritropoetik serta informasi tambahan yang berguna di samping nilai hitung retikulosit. Peningkatan retikulosit imatur umumnya terjadi pada regenerasi sumsum tulang pasca kemoterapi atau transplantasi sumsum tulang dan pasca terapi anemia sehingga dapat digunakan untuk mengikuti hasil pengobatan anemia ${ }^{7}$. Anemia secara fungsional didefinisikan sebagai penurunan massa eritrosit dengan akibat oksigenasi jaringan tidak dapat terpenuhi.
Beberapa jenis anemia yang ada pada pasien tuberkulosis yaitu anemia penyakit kronis, merupakan salah satu penyebab tersering anemia pada penderita. Anemia penyakit kronis ditemukan pada $72 \%$ penderita tuberkulosis yang mengalami infiltrasi ke sumsum tulang ${ }^{8}$.

Pengobatan tuberkulosis dengan obat anti tuberkulosis (OAT) utama yaitu meliputi isoniazid, rifampisin, etambutanol, streptomisin, dan pirazinamid. Isoniazid atau yang sering disingkat INH dapat menyebabkan demam, reaksi hematologik seperti anemia, agranulositosis, eosinofilia dan trombositopenia. Rifampisin juga mempunyai efek samping terhadap reaksi hematologik seperti anemia dan trombositopenia. Sebagian besar Obat Anti Tuberkulosis (OAT) dapat diterima dalam terapi, namun mempunyai efek toksik yang potensial diantaranya terhadap efek samping reaksi hematologik seperti anemia, agranulositosis, eosinofilia dan trombositopenia. Tujuan pengobatan tuberkulosis adalah memusnahkan basil tuberkulosis dengan cepat dan mencegah kekambuhan. Pengobatan tuberkulosis harus selalu mengikuti dua tahapan yaitu tahap intensif dan tahap lanjutan. Pada tahap intensif pengobatan diberikan setiap hari selama 2 bulan dimaksudkan agar

Meditory | ISSN Online : 2549-1520, ISSN Cetak : 2338 - 1159, Vol. 6, No. 1, Juni 2018 
Sri Aprilianti Idris, Gambaran Retikulosit terhadap Pemberian Obat Anti Tuberkulosis (OAT) pada Pasien Tuberkulosis Paru di Puskesmas Perumnas Kadia Kota Kendari

secara efektif menurunkan jumlah kuman yang ada dalam tubuh pasien. Pada tahap lanjutan pasien diberikan jenis obat yang lebih sedikit, namun dalam jangka waktu yang lebih lama yaitu 4 bulan, tahap lanjutan sangat penting untuk mencegah terjadinya kekambuhan ${ }^{1}$.

\section{Metode Penelitian}

Jenis penelitian yang digunakan adalah penelitian deskriptif untuk mengetahui gambaran retikulosit terhadap pemberian Obat Anti Tuberkulosis (OAT) pada pasien tuberkulosis paru. Penelitian dilakukan di dua tempat yaitu pengambilan sampel di Puskesmas Perumnas Kadia Kota Kendari dan pemeriksan retikulosit dilakukan di Laboratorium Hematologi Politeknik Bina Husada.

Populasi dalam penelitian ini adalah semua pasien penderita tuberkulosis paru yang mengkonsumsi OAT di Puskesmas Perumnas Kadia Kota Kendari. Sampel dalam penelitian ini adalah pasien tuberkulosis paru yang sedang menjalani pengobatan OAT di Puskesmas Perumnas Kadia Kota Kendari. Sampel diambil secara accidental sampling.

Penelitian dilakukan dengan menggunakan metode Supravital (Brilliant Cresyl Blue) dengan sediaan kering. Darah yang telah diambil pada pasien penderita tuberkulosis paru yang mengkonsumsi OAT kemudian dicampur dengan larutan Brilliant Cresyl Blue (BCB), kemudian dibuat sediaan apus tipis dan jumlah retikulositnya dihitung dibawah mikroskop. Jumlah retikulosit dihitung per 1000 eritrosit dan dinyatakan dalam \%. Rumus perhitungan retikulosit:

$$
\begin{aligned}
& \% \text { Retikulosit } \\
& =\frac{\sum \text { Retikulosit }}{1000 \text { eritrosit }} \times 100 \%
\end{aligned}
$$

\section{Hasil Penelitian}

1. Distibusi sampel berdasarkan kelompok umur

Tabel 1 Distribusi sampel menurut umur pasien yang mengkonsumsi Obat Anti Tuberkulosis (OAT) di Puskesmas Perumnas Kadia Kota Kendari.

\begin{tabular}{|c|c|c|}
\hline Umur (Tahun) & Frekuensi (Pasien) & Persentase (\%) \\
\hline $18-33$ & 5 & 28 \\
\hline $34-49$ & 4 & 22 \\
\hline $50-67$ & 9 & 50 \\
\hline Total & 18 & 100 \\
\hline
\end{tabular}

Tabel 1 menunjukkan pasien dengan umur 18-33 tahun sebanyak 5 orang $(28 \%)$, pasien dengan umur 3449 tahun sebanyak 4 orang (22\%),

Meditory | ISSN Online : 2549-1520, ISSN Cetak : 2338 - 1159, Vol. 6, No. 1, Juni 2018

HIm. 61 - 69, http://ejournal.poltekkes-denpasar.ac.id /index.php/M 
sedangkan pasien dengan umur 50-67

tahun sebanyak 9 orang (50\%).
2. Distribusi kelompok berdasarkan jenis kelamin

Tabel 2 Distribusi sampel menurut jenis kelamin pasien yang mengkonsumsi Obat Anti Tuberkulosis (OAT) di Puskesmas Perumnas Kadia Kota Kendari

\begin{tabular}{|c|c|c|}
\hline $\begin{array}{c}\text { Jenis } \\
\text { Kelamin }\end{array}$ & Frekuensi (Pasien) & Persentase (\%) \\
\hline L & 7 & 39 \\
\hline P & 11 & 61 \\
\hline Total & 18 & 100 \\
\hline
\end{tabular}

Tabel 2 menunjukkan jumlah

pasien laki-laki sebanyak 7 orang (39\%) dan jumlah pasien perempuan sebanyak 11 orang $(61 \%)$ dari total jumlah pasien sebanyak 18 orang $(100 \%)$.
3. Distribusi kelompok berdasarkan lama pengobatan pasien yang mendapat perawatan paket Obat Anti Tuberkulosis (OAT) di Puskesmas Perumnas Kadia Kota Kendari.

Tabel 3 Distribusi sampel menurut lama pengobatan pasien yang mendapat perawatan paket Obat Anti Tuberkulosis (OAT) di Puskesmas Perumnas Kadia Kota Kendari

\begin{tabular}{|c|c|c|}
\hline Lama Pengobatan & Frekuensi (Pasien) & Persentase (\%) \\
\hline 1-3 Bulan & 8 & 44 \\
\hline 4-6 Bulan & 10 & 56 \\
\hline Total & 18 & 100 \\
\hline
\end{tabular}

Berdasarkan tabel 3, pada

waktu 1-3 bulan pengobatan jumlah pasien sebanyak 8 orang $(44 \%)$, sedangkan pada waktu 4-6 bulan jumlah pasien sebanyak 10 orang $(56 \%)$.

Meditory | ISSN Online : 2549-1520, ISSN Cetak : 2338 - 1159, Vol. 6, No. 1, Juni 2018 HIm. $61-69$, http://ejournal.poltekkes-denpasar.ac.id/index.php/M 
Sri Aprilianti Idris, Gambaran Retikulosit terhadap Pemberian Obat Anti Tuberkulosis (OAT) pada Pasien Tuberkulosis Paru di Puskesmas Perumnas Kadia Kota Kendari

4. Hasil Pemeriksaan retikulosit penderita TB paru

Tabel 4 Distribusi frekuensi hasil pemeriksaan retikulosit

\begin{tabular}{|c|c|c|c|}
\hline \multicolumn{4}{|c|}{ Hasil Pemeriksaan Retikulosit } \\
\hline \multicolumn{2}{|c|}{ Normal } & \multicolumn{2}{c|}{ Tidak Normal } \\
\hline $\begin{array}{c}\text { Frekuensi } \\
\text { (Pasien) }\end{array}$ & Persentase (\%) & $\begin{array}{c}\text { Frekuensi } \\
\text { (Pasien) }\end{array}$ & Persentase (\%) \\
\hline 2 & 11 & 16 & 89 \\
\hline
\end{tabular}

Tabel 4 menunjukkan nilai retikulosit yang normal sebanyak 2 orang (11\%) dan nilai retikulosit tidak normal sebanyak 16 orang $(89 \%)$.

\section{Pembahasan}

Sampel pada penelitian ini adalah pasien tuberkulosis yang mengkonsumsi Obat Anti Tuberkulosis (OAT) di Puskesmas Perumnas Kadia Kota Kendari yang berjumlah 18 orang. Penelitian ini bertujuan untuk mengetahui gambaran retikulosit terhadap pemberian Obat Anti Tuberkulosis (OAT) pada pasien tuberkulosis paru di Puskesmas Perumnas Kadia Kota Kendari. Pada umumnya penderita tuberkulosis mengalami anemia. Anemia merupakan keadaan dimana masa eirtrosit atau masa hemoglobin yang beredar tidak dapat memenuhi fungsinya untuk menyediakan oksigen bagi jaringan tubuh ${ }^{9}$. Anemia dapat disebabkan oleh kekurangan satu atau lebih zat gizi esensial (zat besi, asam folat, vitamin B12) yang digunakan dalam pembentukan sel-sel darah merah ${ }^{10}$.

Seluruh infeksi kronik termasuk TB dapat menyebabkan anemia. Keadaan ini diduga akibat adanya respon dari sistem imun, dimana sel-selnya melepaskan sitokin yang akan membantu dalam hal pemulihan atau mekanisme pertahanan tubuh terhadap infeksi. Akan tetapi, produksi dari sitokin ini juga dapat memengaruhi fungsi normal dari tubuh. Pada anemia penyakit kronik, sitokin dapat mengganggu kemampuan tubuh dalam menyerap dan menggunakan zat besi. Selain itu, produksi dari sitokin yang berlebihan ini juga dapat mengganggu produksi dan aktivitas eritropoietin, hormon yang menstimulasi sumsum tulang untuk memproduksi sel darah merah, sehingga menyebabkan anemia ${ }^{11}$.

Penyakit TB paru merupakan suatu penyakit infeksi kronik yang dalam perjalanan patogenesisnya dapat mengakibatkan berkurangnya persediaan

Meditory | ISSN Online : 2549-1520, ISSN Cetak : 2338 - 1159, Vol. 6, No. 1, Juni 2018 
zat besi dalam tubuh. Anemia penyakit kronik sering bersamaan dengan anemia defisiensi besi dan keduanya memberikan gambaran penurunan besi serum ${ }^{11}$.

Berdasarkan hasil penelitian distribusi sampel menurut umur dimana sampel terbanyak adalah pasien yang berumur 5067 tahun sebanyak 9 orang (50\%), disebabkan pada usia produktif memiliki resiko 5-6 kali untuk mengalami kejadian TB paru, hal ini karena pada kelompok usia produktif setiap orang akan cenderung beraktivitas tinggi, sehingga kemungkinan terpapar kuman Mycobacterium tuberculosis lebih besar. Sedangkan pada umur $\geq 60$ tahun tergolong lansia yang mempunyai kekebalan menurun seiring dengan proses menua maka seluruh fungsi organ mengalami penurunan, kemampuan untuk melawan kuman Mycobacterium tuberculosis lemah sehingga kuman mudah masuk ke dalam tubuh lansia ${ }^{12}$. Berdasarkan hasil penelitian distribusi sampel menurut jenis kelamin terdiri dari laki-laki 7 orang (39\%) dan perempuan sebanyak 11 orang (61\%), sehingga dalam penelitian ini perempuan lebih banyak dibandingkan laki-laki. Berdasarkan hasil penelitian distribusi sampel menurut lama pengobatan pasien yang mendapat perawatan paket Obat Anti Tuberkulosis
(OAT) terbanyak yaitu 4-6 bulan dengan jumlah 10 orang (\%).

Pengobatan tuberkulosis dengan obat anti tuberkulosis (OAT) utama yaitu meliputi isoniazid, rifampisin, etambutanol, streptomisin, dan pirazinamid $^{1}$. Obat Anti Tuberkulosis (OAT) ini dapat menimbulkan banyak efek samping kelainan hematologis diantaranya adalah anemia, trombositosis, trombositopenia, leukositosis, leukopenia dan eosinofilia ${ }^{13}$.

Pengobatan TB diberikan dalam 2 tahap, yaitu tahap intensif dan lanjutan. Pada tahap intensif (awal) pasien mendapat obat setiap hari dan perlu diawasi secara langsung untuk mencegah terjadinya resistensi obat. Bila pengobatan tahap intensif tersebut diberikan secara tepat, biasanya pasien menjadi tidak menular dalam kurun waktu 2 minggu. Sebagian besar pasien TB BTA positif menjadi BTA negatif dalam 2 bulan. Sedangkan pada tahap lanjutan pasien mendapat jenis obat lebih sedikit, namun dalam jangka waktu yang lebih lama. Tahap lanjutan penting untuk membunuh kuman persisten sehingga mencegah terjadinya kekambuhan ${ }^{14}$.

Pada hasil penelitian didapatkan hasil tidak normal, disebabkan sel darah merah yang tidak normal karena penyakit

Meditory | ISSN Online : 2549-1520, ISSN Cetak : 2338 - 1159, Vol. 6, No. 1, Juni 2018 
tuberkulosis dapat menimbulkan kelainan hematologi, baik sel-sel hematopoiesis maupun komponen plasma. Kelainankelainan tersebut sangat bervariasi dan kompleks. Kelainan-kelainan hematologis ini dapat merupakan bukti yang berharga sebagai petanda diagnosis, pentunjuk adanya komplikasi atau merupakan komplikasi Obat Anti Tuberkulosis $(\mathrm{OAT})^{8}$. Salah satu sel darah yaitu retikulosit (eritrosit muda). Retikulosit merupakan eritrosit muda yang tidak berinti dan berasal dari proses pematangan normoblas di sumsum tulang ${ }^{6}$. Pasien dengan nilai retikulosit yang tidak normal dikarenakan kekurangan zat besi dalam tubuh, jarang mengkonsumsi makanan yang kaya nutrisi dan pengaruh Obat Anti Tuberkulosis (OAT) yang dapat mengganggu produksi dan aktivitas eritropoietin $^{11}$.

Secara garis besar patogenesis anemia penyakit kronis dititikberatkan pada 3 abnormalitas utama, yaitu ketahanan hidup eritrosit yang memendek akibat terjadinya lisis eritrosit lebih dini, adanya respon sumsum tulang akibat respon eritropoetin yang terganggu atau menurun, gangguan metabolisme berupa gangguan penyerapan zat besi. Penyakit TB paru merupakan infeksi multi sistemik yang dapat menyebabkan manifestasi di berbagai organ, salah satunya adalah berupa kelainan hematologi ${ }^{11}$.

\section{Kesimpulan}

Berdasarkan hasil penelitian yang telah dilakukan terhadap 18 sampel jumlah retikulosit pasien yang mengkonsumsi Obat Anti Tuberkulosis (OAT) di Puskesmas Perumnas Kadia Kota Kendari di peroleh nilai retikulosit normal sebanyak 2 orang $(11 \%)$ dan yang tidak normal sebanyak 16 orang (89\%).

\section{Daftar Pustaka}

1. Thuraidah A., Astuti WAR., \& Rakhmina D. (2017). Anemia dan Lama Konsumsi Obat Anti Tuberculosis. Medical Laboratory Technology J, 3(2) : 42-46.

1. [WHO]World Health Organization. (2014). Global Tuberculosis Report 2014.

2. [WHO] World Health Organization. (2017). Global Tuberculosis Report 2017.

3. Kemenkes RI. (2016). Profil Kesehatan Sulawesi Tenggara Tahun 2015. Kendari.

4. Oehadian A. (2012). Pendekatan Klinis dan Diagnosis Anemia. CDK-194, 39(6) : 407-412.

5. Suega K. (2010). Aplikasi Klinis Retikulosit. J Peny, 11(3) : 191201.

6. Siladjaja LC. (2014). Profil Maturitas Retikulosit pada Orang Dewasa Normal Serta Pembawa Sifat Thalasemia- $\beta$ atau Hemoglobin E. [Tesis]. Jakarta: FK Universitas Indonesia.

7. Suhartati R., \& Alwi Y. (2015). Gambaran Indeks Eritrosit pada Pasien Tuberkulosis Paru. $J$

Meditory | ISSN Online : 2549-1520, ISSN Cetak : 2338 - 1159, Vol. 6, No. 1, Juni 2018 
Kesehatan Bakti Tunas Husada, 14(1) : 29-33.

9. Masrizal. (2007). Anemia Defisiensi Besi. $J$ Kesehatan Masyarakat, 2(1):

10. Sadewo WS., Salam A., \& Realita A. (2016). Gambaran Status Anemia pada Pasien Tuberkulosis Paru di Unit Pengobatan Penyakit Paru-Paru Provinsi Tahun Kalimantan Barat 2010-2012. J Cerebellum, 2(3) : 590-600.

11. Andayani S., \& Astuti Y. (2017) Prediksi Kejadian Penyakit Tuberkulosis Paru Berdasarkan Usia di Kabupaten Ponorogo Tahun 2016-2020. Indonesia J for health sciences, 1(2) : 29-33.

12. Herawati V. (2016). Gambaran Kadar Hemoglobin pada Penderita Tuberkulosis yang Menjalani Pengobatan Akhir Bulan Ke II dan Akhir Bulan Ke VI di RSUD Ciamis Tahun 2016. [Skripsi]. Ciamis: STIKES Muhammadiyah.

13. Kemenkes RI. (2011). Pedoman Nasional Pengendalian Tuberkulosis. Jakarta.

14. Buntuan V. (2014). Gambaran Basil Tahan Asam (BTA) Positif pada Penderita Diagnosa Klinis Tuberkulosis Paru di Rumah Sakit Islam Sitti Maryam Manado Periode Januari 2014 S/D Juni 2014. J e-Biomedik (eBM), 2(2) : 593-596.

15. D'Hiru. (2013). Live Blood Analysis. Setetes Darah Anda dapat Mengungkapkan Status Kesehatan dan Penyakit yang Mengancam Anda. Jakarta : Gramedia Pustaka Utama.

16. Erma KN., \& Supriyadi. (2012). Penurunan Jumlah Eritrosit Darah Tepi Akibat Paparan Radiasi Sinar X Dosis Radiografi Periapikal. $J$ Stomatognatic (J. K. G Unej), 9(3) : 140-144.
8. Bakta IM. (2006). Hematologi Klinik Ringkas. Jakarta : EGC. 140-145.

17. Gandasoebrata R. (2013). Penuntun Laboratorium Klinik. Jakarta : Dian Rakyat.

18. Handayani W., \& Haribowo AS. (2012). Asuhan Keperawatan pada Klien dengan Gangguan Sistem Hematologi. Jakarta : Salemba Medika.

19. Kiswari R. (2014). Hematologi Dan Transfusi. Semarang : Erlangga.

20. Kemenkes RI. (2014). Pedoman Nasional Pengendalian

Tuberkulosis . Diakses tanggal 15 Januari 2018 dari http://www.tbindonesia.or.id/opend ir/Buku/bpn_p tb_2014.pdf

21. Liliyani E. (2016). Perbedaan Hasil Pemeriksaan Jumlah Retikulosit Metode Mikroskopis dan Flowcytometri. [Skripsi]. Semarang : Universitas Muhammadiyah.

22. Mukti LA., Puspandari AD., \& Muttaqien. (2015). End TB. Jakarta: Forum Stop TB Partnership Indonesia.

23. Rian S. (2010). Pengaruh Efek Samping Obat Anti Tuberkulosis Terhadap Kejadian Default di Rumah Sakit Islam Pondok Kopi Jakarta Timur. [Tesis]. Jakarta : FKM Universitas Indonesia.

24. Setyawati., Pembantjanawa E., \& Rosita L. (2007). Hubungan Antara Indeks Produksi Retikulosit (IPR) dengan Red Blood Cell Distribution Width (RDW) pada Klasifikasi Anemia Berdasarkan Defek Fungsional. J Kedokteran Yarsi, 16(1) : 63-71.

25. Tristyanto N. (2016). Pola Hubungan Antara Jumlah

Meditory | ISSN Online : 2549-1520, ISSN Cetak : 2338 - 1159, Vol. 6, No. 1, Juni 2018

HIm. 61 - 69, http://ejournal.poltekkes-denpasar.ac.id /index.php/M 
Sri Aprilianti Idris, Gambaran Retikulosit terhadap Pemberian Obat Anti Tuberkulosis (OAT) pada Pasien Tuberkulosis Paru di Puskesmas Perumnas Kadia Kota Kendari

Retikulosit dengan Mean

Corpuscular Volume (MCV) : 61-

68. [Diakses tanggal 18 Desember

2017 dari

http://journalhealthyscience.com/w

p-content/uploads/2016/05/02-

092914-nugroho.pdf

Meditory | ISSN Online : 2549-1520, ISSN Cetak : 2338 - 1159, Vol. 6, No. 1, Juni 2018

HIm. $61-69$, http://ejournal.poltekkes-denpasar.ac.id/index.php/M 
